\title{
The Research of Influence Factors of Online Behavioral Advertising Avoidance
}

\author{
Wen Li, Ziying Huang \\ School of Business Administration, South China University of Technology, Guangzhou, China \\ Email: hzy1223@foxmail.com
}

How to cite this paper: Li, W. and Huang, Z.Y. (2016) The Research of Influence Factors of Online Behavioral Advertising Avoidance. American Journal of Indus trial and Business Management, 6, 947957.

http://dx.doi.org/10.4236/ajibm.2016.69092

Received: August 11, 2016

Accepted: September 11, 2016

Published: September 14, 2016

Copyright $\odot 2016$ by authors and Scientific Research Publishing Inc. This work is licensed under the Creative Commons Attribution International License (CC BY 4.0).

http://creativecommons.org/licenses/by/4.0/

\section{(c) (i) Open Access}

\begin{abstract}
With the development of information technology, it's possible to deliver advertising more accurately. Online behavioral advertising (OBA) is a kind of advertising which tracks individual online behavior in order to deliver advertising tailored to his or her interests. However, consumers still avoid advertising with more precise delivery. We can't find out the measures which decrease OBA avoidance unless we know about the factors that influence the avoidance. This paper reviewed researches about advertising avoidance and built the model of OBA avoidance combining the characteristics of OBA. Goal Impediment, Perceived Personalization and Privacy Concern are the independent variables and Negative Experience is the intervening variable. The empirical study finds that Goal Impediment and Privacy Concern are related to OBA avoidance positively, and Perceived Personalization is related to OBA avoidance negatively.
\end{abstract}

\section{Keywords}

Online Behavioral Advertising, Advertising Avoidance,

Perceived Personalization, Privacy Concern

\section{Introduction}

Online Behavioral Advertising (OBA) is a special form of targeted advertising. It is a kind of advertising which collects individual information of online behavior to decide what should show to consumers [1]. It can track consumer's personal information (including his or her searching history, browsing history, purchase history, geography and life interests, etc.) and analyze consumer's preference and personal characteristics to deliver ad based on tracking data [2]. Targeted ad makes it possible for marketers to do one on one marketing communication. Information will spread to target customers more accurately which will improve the effectiveness and efficiency of dissemination. 
It benefits marketers but the online behavioral advertising is generally considered undesirable and consumers still avoid it. Mozilla [3] reported that Adblock Plus, a function available on the Firefox Web browser, is used by approximately 13 million people. The survey about ads view of Chinese urban residents also shows that about $36 \%$ of urban residents will ignore or avoid TV commercials and $62 \%$ of them will ignore or avoid online ads [4]. Turow [5] found that $66 \%$ of adults do not want marketing people to provide customized advertising based on their personal interest, and when they learned that the main form of personal information is collected, the percentage rises to $73 \%-86 \%$.

Over the past five decades, there has been a well-articulated body of academic research on advertising avoidance [6]-[9]. With the wide application of Internet, potential determinants of advertising avoidance of online media have emerged as an important focus of research inquiry to provide insights that may suggest strategic ways to decrease advertising avoidance [10]-[12]. However, few studies have examined the factors of online behavioral advertising avoidance. When consumers are faced with the personalized and customized ads, the factors that cause their avoidance are unknown. Therefore, on the basis of reviewing previous studies, the paper developed a theoretical model to examine the key factors of OBA's avoidance. An understanding of what drives OBA's avoidance can not only help advertising scholars develop a comprehensive theoretical framework of ad avoidance that goes beyond traditional mass advertising, but can also help marketers fine-tune their direct marketing communication strategies to decrease consumer avoidance.

\section{Literature Review}

\subsection{Advertising Avoidance}

Advertising avoidance is considered to be one of the biggest obstacles of advertising and it has been a focus for researchers to find out the determinants of ad avoidance. Ad avoidance is defined by Speck and Elliott [13] as "all actions by media users that differentially reduce their exposure to ad content". Many early studies explored the audience avoidance behavior on television, radio, newspapers, magazines and other traditional media. Clancey [14] found that audience avoid ads by ignoring distracting ads which is cognitive avoidance, leaving the room which is physical avoidance, changing the channel which is mechanical avoidance. Speck and Elliott [13] found that in the traditional media, the factors affecting ads avoidance are demographic characteristics (gender, age, income), ads perception (advertising interruption), communication problems (search barrier) and so on.

In recent years, scholars have focused on the exploration about ads avoidance on the Internet [11] [14]-[16]. Many prior researches conceptualizes ad avoidance as a tripartite disposition composed of cognitive, affective, and behavioral components, namely cognitive avoidance, affective avoidance and behavioral avoidance [11] [12] [17]. Cognitive ad avoidance is the psychological defense mechanism that results in users intentionally ignoring an ad they are exposed to [17]. Cognitive avoidance is rooted in consumers' beliefs about ads, which can lead to them deliberately ignoring an ad. Affective 
ad avoidance, on the other hand, involves negative feelings and the expression of emotional reactions toward an advertisement [18] [19]. Behavioral avoidance is "consumer avoidance actions other than lack of attendance" [11]. This article is also measured by these three dimensions of ads avoidance in the context of online behavioral advertising as follows: consumers deliberately ignore any ads (cognitive avoidance), hate online behavioral ads (affective avoidance), close or intercept online behavioral ads (behavioral avoidance).

\subsection{Goal Impediment}

Goal impediment has been considered as one of the most significant predictors of ad avoidance. The Internet is a goal-oriented medium where users are usually engaged in pursuing specific tasks that can be interrupted by exposure to unsolicited ads, which will make consumers have negative experiences and ads avoidance. Li et al. [20] found that the perception about advertising interruption will result in the cognitive avoidance and behavioral avoidance directly. Speck and Elliott [13] also found that, interrupted by advertising will directly affects consumers' advertising avoidance behavior. Consumers may also occur negative emotions because the advertising content is not consistent with the webpage they are browsing [21]. Therefore, we propose the following hypotheses:

H1a: Goal Impediment is related to negative experience of online behavioral advertising positively.

H1b: Goal Impediment is related to avoidance of online behavioral advertising positively.

\subsection{Privacy Concern}

Privacy concern is defined as "the degree of consumers' concern about potential privacy was invaded" [22]. With the rapid advances of information processing and communication technologies, most marketers collect and track personal information about specific consumer purchase histories and characteristics to identify the best prospects, customized advertising, and promotion strategies; implement highly targeted directmarketing efforts; and establish reward and loyalty programs [23]-[25]. However, information privacy is a great concern to consumers [26] [27]. These marketing tools will make consumers to worry about their privacy has potentially exposed. Privacy concern has a negative impact to consumers' buying behavior, trust and information control [28]. Whether the privacy is protected influences consumers' trust in e-commerce a lot [2]. With the intensification of privacy concern, consumers are likely to have a negative experience and avoid online behavioral advertising such as don't provide complete information, cancel or block ads, or make a very bad comments about the ads [29]. Therefore: we propose the second hypotheses:

H2a: Privacy concern is related to negative experience of online behavioral advertising positively.

$\mathrm{H} 2 \mathrm{~b}$ : Privacy concern is related to avoidance of online behavioral advertising positively. 


\subsection{Perceived Personalization}

Perceived Personalization refers to the process that is customizing solutions according to consumers' information [30]; it is the personal communication on the basis of individual preference [31]. The biggest difference between online behavioral advertising and traditional advertising is that OBA is customized; it is personalized. Prior research [32] has further asserted that consumer reactance to personalized messages can be determined by whether the perceived utility of the advertised products or services offsets the psychological costs of receiving inappropriate personal messages. Perceived utility (e.g., some rewards and benefits from the restricted freedom) significantly decreases consumer reactance against the loyalty program [32]. Studies [33] also found that personalized content is the most effective way to avoid the ads that are regarded as disturbing. When the ads are considered useful and valuable, consumers are inclined to have positive experience to ads and have a lower rate of ads avoidance. Therefore, we propose hypothesis 3 :

H3a: Privacy concern is related to negative experience of online behavioral advertising negatively.

H3b: Privacy concern is related to avoidance of online behavioral advertising negatively.

\subsection{Negative Experience}

Consumer advertising experience also has a significant impact on consumer attitudes and behavior [34] [35]. In previous studies [11], prior negative experience is one of independent variables, which is from consumer's learning perspective; the consumer prior experience will affect the type and manner of information processing. This article is from perspective of "perception, attitude, and practice". When consumers are contacted with the online behavioral advertising, goal impediment, privacy concerns and perceived personalization will affect the consumer experience immediately the $\mathrm{n}$ affect consumers' attitude and behavior. For online behavioral advertising, the negative experiences may include lack of usefulness, lack of incentive, and so on. Consumers will avoid the sources generating negative experience. Accordingly, we propose hypothesis 4:

H4: Negative experience is related to avoidance of online behavioral advertising positively.

The theoretical model of this paper is shown by Figure 1 .

\section{Research Method}

\subsection{Questionnaire Design}

We collected the data through questionnaire. Questionnaire is divided into two parts. The first part is basic information, including gender, age, education, duration, and daily access. The second part is a measure of the model five variables including a total of 26 problem items. All measurement scales are from prior research and adjusted according to the research target. Goal impediment adopts three question items from Cho \& 


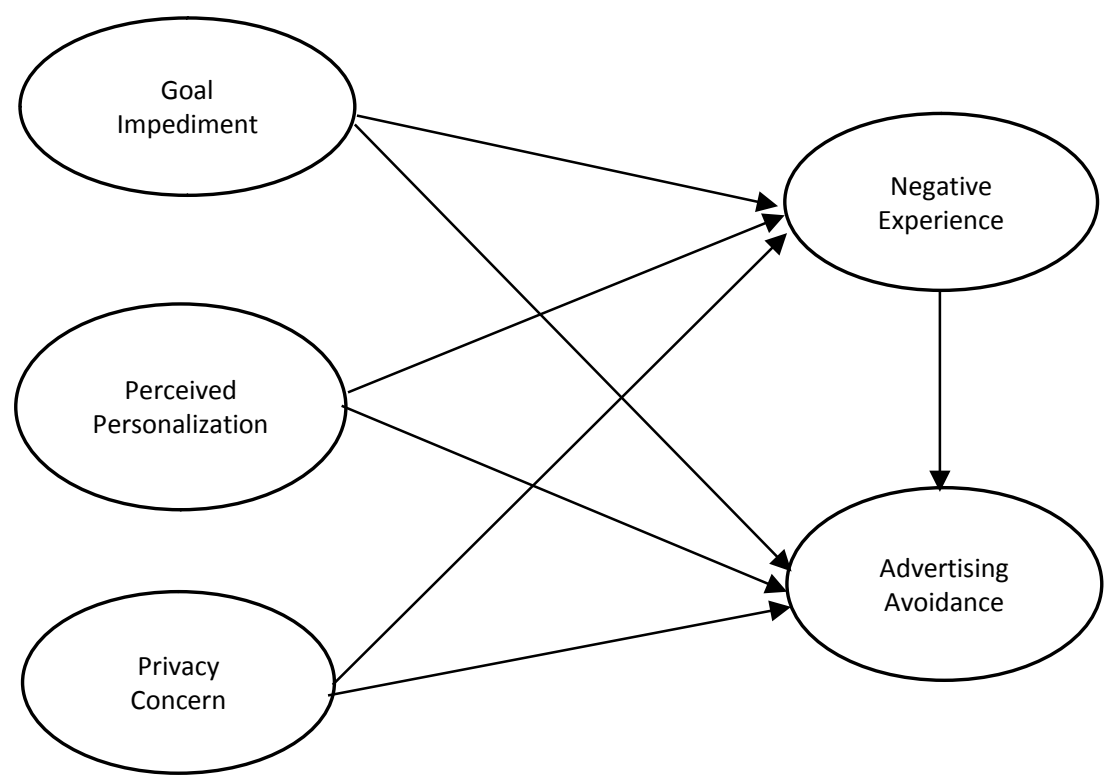

Figure 1. The theoretical model.

Cheon's [11] research; privacy concern adopts the scale from Malhotra [36], Shintaro et al. [37]; perceived personalization is measured by the scale of Hyejin [38] and Srinivasan's research [39] negative experience adopts four question items from Seyedghorban [16]; advertising avoidance is measured by scale from Cho \& Cheon [11].

All variables used five-point Likert scale to measure. Likert scale is used widely in the current study, which asks subjects to express their own views to a set of statement related to the topic. Using five-point Likert scales $(1=$ strongly disagree and $5=$ strongly agree), five latent constructs-advertising avoidance, goal impediment, perceived personalization, privacy concern, and negative experience-were measured in this study.

\subsection{Sample Description}

Questionnaires were issued and collected from May 18 to May 25, 2016. We collected questionnaires online and offline. There are 154 online questionnaires and 120 offline questionnaires. We chose the largest CBD of Guangzhou, Pearl River New City to distribute questionnaires.

There are valid 231 questionnaires excluding the non-standard questionnaires and the effective rate is $84.3 \%$. In the recovered sample, men are $64.5 \%$ and women accounted for $35.5 \%$; the population between the ages of $18-35$ accounted for $88.9 \%$. $83.1 \%$ of the sample population has a university degree or above; $33.3 \%$ of the population's online time is $1-2$ hours per day and $35.1 \%$ of the population daily online time is 3 - 4 hours.

\section{Results}

\subsection{Reliability and Validity}

The research used AMOS20.0 and SPSS17.0 software to test reliability and validity. As 
shown in Table 1, all variables' Cronbach's $\alpha$ values are greater than 0.7 and it has reached the requirements. It means that the scale of this paper has good reliability.

In this paper, the scales are mature scales referring to the prior research and modified according to the purpose of this study, which has good content validity. From Table 1, the factor loading of all variables are greater than 0.6; composite reliability (CR) values of each variable is greater than 0.8 and average variance extracted (AVE) is greater than 0.5 , which indicates that the measurement scale has good convergent validity. From Table 2, the square root of AVE values of each variable is greater than the correlation coefficient with other variables, which means that scale has good discriminant validity.

Table 1. The summary of reliability and validity.

\begin{tabular}{|c|c|c|c|}
\hline Variables & Questions & Factor Loading & Cronbach's $\alpha$, AVE, CR \\
\hline \multirow{9}{*}{$\begin{array}{l}\text { Advertising } \\
\text { Avoidance }\end{array}$} & I deliberately ignore online behavioral ads when I'm surfing on the Internet & 0.864 & \multirow{9}{*}{$\begin{array}{c}\text { Cronbach’s } \\
\alpha=0.961 \\
\text { AVE }=0.601 \\
\text { CR }=0.931\end{array}$} \\
\hline & I deliberately ignore online behavioral ads when I'm browsing on the shopping sites & 0.792 & \\
\hline & I deliberately ignore online behavioral ads when I open my mailbox & 0.776 & \\
\hline & Online behavioral ads are annoyed & 0.792 & \\
\hline & Online behavioral ads make me feel disturbed & 0.779 & \\
\hline & Online behavioral ads are unappealing & 0.804 & \\
\hline & If online behavioral ads pop out, I will close them & 0.698 & \\
\hline & I'll take some measures (such as setting the browser) to avoid online behavioral ads & 0.758 & \\
\hline & I will remove/unsubscribe online behavioral ads & 0.700 & \\
\hline \multirow{3}{*}{$\begin{array}{l}\text { Goal } \\
\text { Impediment }\end{array}$} & These ads increases the obstacle during search & 0.851 & \multirow{3}{*}{$\begin{array}{c}\text { Cronbach's } \\
\alpha=0.909 \\
\text { AVE }=0.722 \\
\text { CR }=0.886\end{array}$} \\
\hline & These ads distracts my attention & 0.871 & \\
\hline & These ads interrupt me to finish my task & 0.827 & \\
\hline \multirow{4}{*}{$\begin{array}{c}\text { Perceived } \\
\text { Personalization }\end{array}$} & These ads provide the information I need & 0.730 & \multirow{4}{*}{$\begin{array}{c}\text { Cronbach's } \\
\alpha=0.886 \\
\text { AVE }=0.568 \\
\text { CR }=0.840\end{array}$} \\
\hline & These ads make purchase recommendations match my needs & 0.768 & \\
\hline & These ads enables me to order products I need more easily & 0.766 & \\
\hline & These ads make me feel that I am an unique customer & 0.749 & \\
\hline \multirow{6}{*}{$\begin{array}{l}\text { Privacy } \\
\text { Concern }\end{array}$} & I feel uncomfortable when information is shared without permission & 0.785 & \multirow{6}{*}{$\begin{array}{c}\text { Cronbach's } \\
\alpha=0.934 \\
\text { AVE }=0.571 \\
\text { CR }=0.889\end{array}$} \\
\hline & I feel that my privacy is invaded if I can’t control my personal information & 0.738 & \\
\hline & It is important for me to know how my personal information is used & 0.790 & \\
\hline & Online behavioral ads’ privacy policies should have a clear explanation & 0.766 & \\
\hline & I'm worried that my record of network activity will be abused & 0.722 & \\
\hline & $\begin{array}{l}\text { When the online behavioral ads need my personal information, } \\
\text { I usually will think about for a while }\end{array}$ & 0.733 & \\
\hline \multirow{4}{*}{$\begin{array}{l}\text { Negative } \\
\text { Experience }\end{array}$} & Online behavioral ads are lack of attraction & 0.835 & \multirow{4}{*}{$\begin{array}{c}\text { Cronbach's } \\
\alpha=0.933 \\
\text { AVE }=0.700 \\
\text { CR }=0.9032\end{array}$} \\
\hline & Online behavioral ads are lack of usefulness & 0.805 & \\
\hline & Online behavioral ads are lack of specificity & 0.849 & \\
\hline & Online behavioral ads are lack of incentives & 0.857 & \\
\hline
\end{tabular}


Table 2. The matrix of the correlation coefficient.

\begin{tabular}{|c|c|c|c|c|c|}
\hline Variables & $\begin{array}{c}\text { Goal } \\
\text { Impediment }\end{array}$ & $\begin{array}{c}\text { Perceived } \\
\text { Personalization }\end{array}$ & $\begin{array}{l}\text { Privacy } \\
\text { Concern }\end{array}$ & $\begin{array}{l}\text { Negative } \\
\text { Experience }\end{array}$ & $\begin{array}{l}\text { Advertising } \\
\text { Avoidance }\end{array}$ \\
\hline Goal Impediment & 0.775 & & & & \\
\hline $\begin{array}{c}\text { Perceived } \\
\text { Personalization }\end{array}$ & 0.644 & 0.849 & & & \\
\hline $\begin{array}{l}\text { Privacy } \\
\text { Concern }\end{array}$ & 0.641 & 0.771 & 0.753 & & \\
\hline $\begin{array}{l}\text { Negative } \\
\text { Experience }\end{array}$ & -0.614 & -0.919 & -0.959 & 0.756 & \\
\hline $\begin{array}{l}\text { Advertising } \\
\text { Avoidance }\end{array}$ & -0.132 & 0.055 & 0.602 & -0.341 & 0.837 \\
\hline
\end{tabular}

The value of diagonal is the square root of AVE.

\subsection{Structural Model and Path Verification}

Amos20.0 was used to explore the relationship between the variables and establish model structure. This model, the absolute fitness X2 $=325.190, \mathrm{df}=292$, GFI $(0.906)$ is greater than 0.90; AGFI (0.887) is greater than 0.80; NFI (0.941) is greater than 0.90; RMR (0.060) is less than 0.08; RMSEA (0.022) is less than 0.08. The indicators reach an acceptable range, which means that the structural model has a good degree of adaptation.

Hypothesis test results are shown in Table 3. From the path coefficients and significance of theoretical model, it can be known that the assumptions are through testing except H3a. Goal impediment is related to negative experiences $(\mathrm{P}<0.001)$ and advertising avoidance $(\mathrm{P}<0.001)$ positively; perceived personalization is related to negative experience $(\mathrm{P}<0.001)$ and advertising avoidance $(\mathrm{P}<0.001)$ negatively; privacy concerns is related to advertising avoidance positively $(\mathrm{P}<0.001)$, but there is no significant impact on the negative experience $(\mathrm{P}>0.05)$; the negative experience is related to advertising avoidance positively $(\mathrm{P}<0.001)$.

\section{Discussions}

\subsection{Theoretical Contributions}

The study established a theoretical model of online behavioral advertising and enriched the theory in the field of advertising avoidance.

First, in the research of traditional advertising, television, newspapers, magazines and other mass media are difficult to customize content of advertising, so it does not require much thought about perceived personalization and privacy concern. However, as the characteristics of online behavioral advertising, it should not ignore the impact of perceived personalization and privacy concern. This study introduced the two new factors into advertising avoidance theoretical model. It's an expansion of the research of advertising avoidance.

Secondly, the research introduced negative experience as a mediator of model. The negative experience is independent variable in the traditional research model, while the 
Table 3. Model test results.

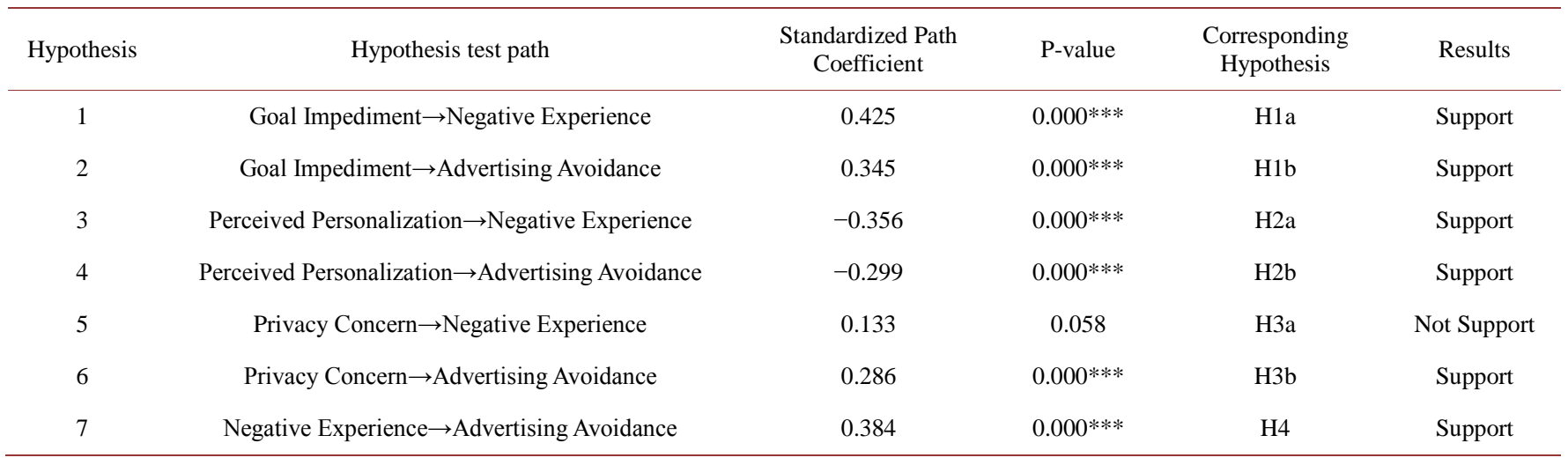

research found that goal impediment and perceived personalization affect the consumer experience and further influence the advertising avoidance. The research found out the more complicated relationship among variables.

\subsection{Management Implications}

Behavioral advertising is popular in the Internet age, and it may become more precise in the future. What factors affect avoidance of online behavioral advertising? How do consumers view privacy and personalization? The paper explores these issues.

From the results, the perceived personalization is related to advertising avoidance negatively. When there is a high degree of personalization, consumers can more easily find the desired product, or to know the incentive timely, so they will think the ads are useful, attractive and incentive and therefore they will have lower degree of negative experience to the ads and have a lower tendency of advertising avoidance. This is consistent with previous studies, targeted advertising will increase the good feeling [40]. Maybe this because personalization will make consumers feel that they have contacted with the company. People are less likely to have negative experience to the company if they had contacted with it before [41]. For companies and businesses, this is an important revelation. More accurate analysis of consumer demand will let consumers reduce the negative experience and ads avoidance.

The correlation between privacy concerns and negative experience is not obvious, and its impact on advertising avoidance is lower than perceived personalization on ads advertising. Even so, companies or businesses should pay attention to consumers' privacy. When collect consumer's information, companies or businesses should promise the security of personal information and ensure that consumers' right to know and control the use of privacy. When the perceived utility from personalization is greater than the psychological loss from privacy concern, the avoidance will decrease.

\subsection{Limitations}

There is insufficient in this research. First, the sample selection: as the younger age groups is the main force of the Internet activities, the sample selected mainly was com- 
posed by university students and young workers. Therefore future research can expand the sample. Second, behavioral targeting advertising is a relatively new kind of forms of advertising, which is closely linked with Internet. Then whether the form of the ads or the network of ads delivering influence the avoidance, can be explored in the future.

\section{Conclusions}

This paper selects the very popular behavioral advertising on the Internet currently to explore the factors that influence consumers to avoid advertising, in order to find ways to alleviate the tendency of consumers' advertising avoidance. On the basis of prior research of advertising avoidance, combined with the characteristics of online behavioral advertising, we established theoretical model and did empirical test by 231 effective questionnaires, then we came to the following conclusions:

- Goal impediment and privacy concern positively influence advertising avoidance. Perceived personalization negatively influences advertising avoidance.

The study found that goal impediment, privacy concerns and perceived personalization had significant impact on advertising avoidance. The more goal impediment, there is more ads avoidance. As a kind of advertising which delivers content according to the consumer's browsing history and purchase history, when consumer's privacy is in high degree, a tendency to avoid advertising is also high. However, when perceived personalization is in high degree, the avoidance is in low degree. When the advertising is considered to be useful and valuable, consumers show a lower level of advertising avoidance.

- The negative experience is an intervening variable to advertising avoidance

The study found that the negative experience played a partial mediating role between the goal impediment, perceived personalization and the advertising avoidance.

\section{References}

[1] McDonald, A.M. and Cranor, L.F. (2010) Americans' Attitudes about Internet Behavioral Advertising Practices. Proceedings of the 9th Annual ACM Workshop on Privacy in the Electronic Society, Chicago, 21 November 2010, 63-72.

[2] Jiang, J., Zhang, H. and Jia, J. (2015) Research of Consumer Privacy Concerns and Behavioral Targeting Advertising (OBA) under Big Data Background. Management World, 8, 182-183.

[3] Mozilla, Add-Ons for FireFox. https://addons.mozilla.org/en-US/statistics/addon/1865/

[4] Chen, S.B. and Cao, X.J. (2013) Influential Factors of Online Advertising AvoidanceBased on 2012 London Olympics Advertising Network. News Media and Research, 12, 5465.

[5] Turow, J., King, J., Hoofnatle, C.J., et al. (2009) Americans Reject Tailored Advertising and Three Activities That Enable It. Departmental Papers (ASC), 137.

[6] Abernethy, A.M. (1990) Television Exposure: Programs vs. Advertising. Journal of Current Issues and Research in Advertising, 13, 61-77.

[7] Bellman, S., Schweda, A. and Varan, D. (2010) The Residual Impact of Avoided Television Advertising. Journal of Advertising, 39, 67-81. 
http://dx.doi.org/10.2753/JOA0091-3367390105

[8] Nuttall, C.G.F. (1962) TV Commercial Audiences in the United Kingdom. Journal of Advertising Research, 2, 19-28.

[9] Rich, T., Owens, D. and Ellenbogen, I. (1978) What Canadians Disliked about TV Commercials. Journal of Advertising Research, 18, 37-44.

[10] Baek, T.H. and Morimoto, M. (2012) Stay away from Me: Examining the Determinants of Consumer Avoidance of Personalized Advertising. Journal of Advertising, 41, 59-76. http://dx.doi.org/10.2753/JOA0091-3367410105

[11] Cho, C.-H. and Cheon, H.J. (2004) Why Do People Avoid Advertising on the Internet? Journal of Advertising, 33, 89-97. http://dx.doi.org/10.1080/00913367.2004.10639175

[12] Edwards, S.M., Li, H.R. and Lee, J.-H. (2002) Forced Exposure and Psychological Reactance: Antecedents and Consequences of the Perceived Intrusiveness of Pop-Up Ads. Journal of Advertising, 31, 83-95. http://dx.doi.org/10.1080/00913367.2002.10673678

[13] Speck, P.S. and Elliott, M.T. (1997) Predictors of Advertising Avoidance in Print and Broadcast Media. Journal of Advertising, 26, 61-76. http://dx.doi.org/10.1080/00913367.1997.10673529

[14] Clancey, M. (1994) The Television Audience Examined. Journal of Advertising Research, 34, 2-11.

[15] Zenetti, G., Bijmolt, T.H.A., Leeflang, P.S.H. and Klapper, D. (2014) Search Engine Advertising Effectiveness in a Multimedia Campaign. International Journal of Electronic Commerce, 18, 7-38. http://dx.doi.org/10.2753/JEC1086-4415180301

[16] Seyedghorban, Z., Tahernejad, H. and Matanda, M.J. (2016) Reinquiry into Advertising Avoidance on the Internet: A Conceptual Replication and Extension. Journal of Advertising, 45, 120-129. http://dx.doi.org/10.1080/00913367.2015.1085819

[17] Prendergast, G.P., Tsang, A.S.L. and Cheng, R. (2014) Predicting Handbill Avoidance in Hong Kong and the UK. European Journal of Marketing, 48, 132-146. http://dx.doi.org/10.1108/EJM-05-2011-0244

[18] Alwitt, L.F. and Prabhaker, P.R. (1994) Identifying Who Dislikes Television Advertising: Not by Demographics Alone. Journal of Advertising Research, 34, 17-29.

[19] Phillips, J. and Noble, S.M. (2007) Simply Captivating: Understanding Consumers' Attitudes toward the Cinema as an Advertising Medium. Journal of Advertising, 36, 81-94. http://dx.doi.org/10.2753/JOA0091-3367360106

[20] Li, H., Edwards, S.M. and Lee, J.-H. (2002) Measuring the Intrusiveness of Advertisements: Scale Development and Validation. Journal of Advertising, 31, 37-47. http://dx.doi.org/10.1080/00913367.2002.10673665

[21] Burns, K.S. and Lutz, R.J. (2006) The Function of Format: Consumer Responses to Six On-Line Advertising Formats. Journal of Advertising, 35, 53-63. http://dx.doi.org/10.2753/JOA0091-3367350104

[22] Baek, T.H. and Morimoto, M. (2012) Stay away from Me: Examining the Determinants of Consumer Avoidance of Personalized Advertising. Journal of Advertising, 41, 59-76. http://dx.doi.org/10.2753/JOA0091-3367410105

[23] Dolnicar, S. and Jordaan, Y. (2007) A Market-Oriented Approach to Responsibly Managing Information Privacy Concerns in Direct Marketing. Journal of Advertising, 36, 123-149. http://dx.doi.org/10.2753/JOA0091-3367360209

[24] Hughes, A.M. (2005), Strategic Database Marketing: The Masterplan for Starting and Managing a Profitable, Customer-Based Marketing Program, 3rd Edition, McGraw-Hill, New York. 
[25] Phelps, J., Glen, N. and Elizabeth, F. (2000) Privacy Concerns and Consumer Willingness to Provide Personal Information. Journal of Public Policy and Marketing, 19, 27-41. http://dx.doi.org/10.1509/jppm.19.1.27.16941

[26] Gurau, C., Ashok, R. and Claire, G. (2003) To Legislate or Not to Legislate: A Comparative Study of Privacy/Personalization Factors Affecting French, UK and US Web Sites. Journal of Consumer Marketing, 20, 652-664. http://dx.doi.org/10.1108/07363760310506184

[27] Nowak, G.J., and Joseph, P. (1992) Understanding Privacy Concerns: An Assessment of Consumers' Information-Related Knowledge and Belief. Journal of Direct Marketing, 6, 2839. http://dx.doi.org/10.1002/dir.4000060407

[28] Milne, G.R. and Boza, M.-E. (1999) Trust and Concern in Consumers' Perceptions of Marketing Information Management Practices. Journal of Interactive Marketing, 13, 5-24. http://dx.doi.org/10.1002/(SICI)1520-6653(199924)13:1<5::AID-DIR2>3.0.CO;2-9

[29] Sheehan, K.B. and Hoy, M.G. (1999) Flaming, Complaining, Abstaining: How Online Users Respond to Privacy Concerns. Journal of advertising, 28, 37-51. http://dx.doi.org/10.1080/00913367.1999.10673588

[30] Rodgers, S., Wang, Y., Ruth, R. and Frank, A. (2007) The Web Motivation Inventory: Replication, Extension, and Application to Internet Advertising. International Journal of Advertising, 26, 447-476.

[31] Roberts, M.L. (2003) Internet Marketing: Integrating Online and Offline Strategies. McGraw-Hill, Boston.

[32] White, T.B., Zarhay, D.L., Helge, T. and Sharon, S. (2008) Getting Too Personal: Reactance to Highly Personalized E-Mail Solicitations. Marketing Letters, 19, 39-50. http://dx.doi.org/10.1007/s11002-007-9027-9

[33] Pasadeos, Y. (1990) Perceived Informativeness of and Irritation with Local Advertising. Journalism Quarterly, 67, 35-39. http://dx.doi.org/10.1177/107769909006700107

[34] Fazio, R.H. and Zanna, M.P. (1981) Direct Experience and Attitude-Behavior Consistency. Advances in Experimental Social Psychology, 14, 161-202. http://dx.doi.org/10.1016/S0065-2601(08)60372-X

[35] Smith, R.E. and Swinyard, W.R. (1982) Information Response Models: An Integrated Approach. The Journal of Marketing, 46, 81-93. http://dx.doi.org/10.2307/1251162

[36] Malhotra, N.K., and Tracey, K. (2003) Don't Negate the Whole Field. Marketing Research, 15, 43-44.

[37] Okazaki, S., Molina, F.J. and Hirose, M. (2012) Mobile Advertising Avoidance: Exploring the Role of Ubiquity. Electronic Markets, 22, 169-183.

[38] Hyejin, K. (2013) Exploring the Effects of Perceived Relevance and Privacy Concerns on Consumer Responses to Online Behavioral Advertising. University of Minnesota, Minnesota. http://dx.doi.org/10.1007/s12525-012-0087-1

[39] Srinivasan, S.S., Anderson, R. and Ponnavolu, K. (2002) Customer Loyalty in E-Commerce: an Exploration of Its Antecedents and Consequences. Journal of Retailing, 78, 41-50. http://dx.doi.org/10.1016/S0022-4359(01)00065-3

[40] Aaker, J.L., Brumbaugh, A.M. and Grier, S.A. (2000) Non-Target Markets and Viewer Distinctiveness: The Impact of Target Marketing on Advertising Attitudes. Journal of Consumer Psychology, 9, 127-140. http://dx.doi.org/10.1207/S15327663JCP0903_1

[41] Morimoto, M. and Chang, S. (2006) Consumer Attitudes toward Unsolicited Commercial E-Mail and Postal Direct Mail Marketing Methods: Intrusiveness, Perceived Loss of Control, and Irritation. Journal of Interactive Advertising, 7, 8-20.

http://dx.doi.org/10.1080/15252019.2006.10722121 
Submit or recommend next manuscript to SCIRP and we will provide best service for you:

Accepting pre-submission inquiries through Email, Facebook, LinkedIn, Twitter, etc. A wide selection of journals (inclusive of 9 subjects, more than 200 journals)

Providing 24-hour high-quality service

User-friendly online submission system

Fair and swift peer-review system

Efficient typesetting and proofreading procedure

Display of the result of downloads and visits, as well as the number of cited articles

Maximum dissemination of your research work

Submit your manuscript at: http://papersubmission.scirp.org/

Or contact ajibm@scirp.org 